\title{
RECOGNITION OF GOLD MINERALIZATION FAVORABILITY ZONES THROUGH AIRBORNE GAMMA-RAY SPECTROMETRY AND MAGNETOMETRY IN BRUSQUE AND BOTUVERÁ REGION, SOUTHERN BRAZIL
}

\author{
Bruno Macchioni Pereira and Francisco José Fonseca Ferreira
}

\begin{abstract}
The northeastern portion of Santa Catarina State, southern Brazil, bears important primary gold mineralization associated with granitic intrusions with potassic and phyllic hydrothermal alteration zones and a phase shear zone reactivation. Airborne radiometric and magnetic data were applied in the study area through the use of gamma-ray spectrometry (Total Count, K, eTh and eU) and suggestive parameters of hydrothermal alteration as Kd, Ud and F, in association with geological units, while magnetometry (RTP, THDR, TDR and Signum Transform) was applied in the definition of the structural framework. Geophysical data was interpreted and integrated to geological information, such as lithologic units, structures, shear zones and gold mineralization, using the knowledge-driven and index overlay methods in order to define favorable targets. The geophysical and geological data exhibit good correlation, as seen in the gamma-ray spectrometric domains and magnetic lineaments, and the favorability map shows important target areas for primary gold mineralization. It was possible to observe in the geophysical maps that shear zones and faults have more influence in the occurrences than potassic and phyllic hydrothermal alteration related to granitic intrusions.
\end{abstract}

Keywords: geophysical exploration, knowledge-driven, Dom Feliciano Belt.

RESUMO. A porção nordeste do estado de Santa Catarina, sul do Brasil, possui importantes mineralizações auríferas primárias associadas a intrusões graníticas com zonas de alteração hidrotermal potássica e fílica e posterior fase de reativação de zonas de cisalhamento. Dados radiométricos e magnéticos aerogeofísicos foram aplicados na área de estudo através do uso de gamaespectrometria (Contagem Total, K, eTh e eU) e parâmetros sugestivos de alteração hidrotermal como Kd, Ud e Parâmetro F. Em associação com unidades geológicas, enquanto a magnetometria (RTP, GHT, ISA e Signum Transform) foi aplicada na definição do arcabouço estrutural. Os dados geofísicos foram interpretados e integrados às informações geológicas, como unidades litológicas, estruturas, zonas de cisalhamento e mineralizações de ouro, utilizando os métodos knowledge-driven e index overlay para definir alvos favoráveis. Os dados geofísicos e geológicos apresentam boa correlação, como visto nos domínios espectrométricos de raios gama e lineamentos magnéticos, e o mapa de favorabilidade mostra áreas-alvo importantes para a mineralização de ouro primária. Foi possível observar nos mapas geofísicos que as zonas de cisalhamento e as falhas têm mais influência nas ocorrências do que as zonas de alteração hidrotermal potássica e fílica relacionadas às intrusões graníticas.

Palavras-chave: exploração geofísica, knowledge-driven, Cinturão Dom Feliciano.

Universidade Federal do Paraná, Department of Geology, Laboratory for Research in Applied Geophysics, R. Francisco Heráclito dos Santos, 100, Building VI, 81531-980, P.0. Box 19045, Curitiba, PR, Brazil -E-mails: brunomacchioni@gmail.com, francisco.ferreira@ufpr.br 


\section{INTRODUCTION}

The northeastern region of Santa Catarina state, south Brazil (Fig. 1), is known for hosting important granitic and volcanic-exhalative gold mineralization; several occurrences have been recognized and described. Caldasso et al. (1995a,b) outlined potential gold exploratory targets by mapping the area, and Biondi et al. (2007) studied various magmatic-hydrothermal mineralization in Botuverá, estimating ore reservoirs of 1 to 2 tons with Au content of 20 to $40 \mathrm{ppm}$. Castro (1997) considered these gold mineralization occurrences to be the most important ones in Santa Catarina state.

Airborne geophysical surveys have been widely applied as supporting methods in geological mapping and mineral exploration. Gamma-ray spectrometry assists in the identification of hydrothermal potassic and phyllic zones, which can potentially be mineralized, while magnetometry helps in the delineation of the structural framework and recognition of magnetic rocks. Irvine \& Smith (1990) consider the use of radiometric and magnetic airborne surveys as a fundamental tool in regional and semi-regional exploration phases, as coincident magnetic and potassium peaks are related to polymettalic deposits (Shives et al., 2000). Fornazzari Neto \& Ferreira (2003) applied radiometric data to the identification of gold mineralization in Botuverá region, based on the analysis of gamma-ray profiles, finding important potential targets.

This study aims to evaluate the concordance of geophysical data from the Paraná - Santa Catarina Aerogeophysical Project (CPRM - Serviço Geológico do Brasil, 2011) with the geological outline of the area, and interpret responses of radiometric and magnetic signals according to the lithological and structural features. Primary gold favorability zones were outlined based on geological-geophysical integration, using the knowledge-driven analysis method.

\section{GEOLOGICAL SETTING}

The eastern part of Santa Catarina consists in the Dom Feliciano Belt (DFB), a fold belt divided into three domains (Basei, 2000; Basei et al., 2010): (a) Internal Domain, formed by calk-alcaline to alcaline granitoids; (b) Central Domain, characterized by a metavolcanosedimentary sequence intruded by several granitic plutons, called Brusque Metamorphic Complex; and (c) External Domain, constituted of a foreland basin denominated Itajaí Group. DFB is the result of several collisions of Proterozoic to early Cambrian terranes during the Brasiliano Cycle (Basei, 2000).

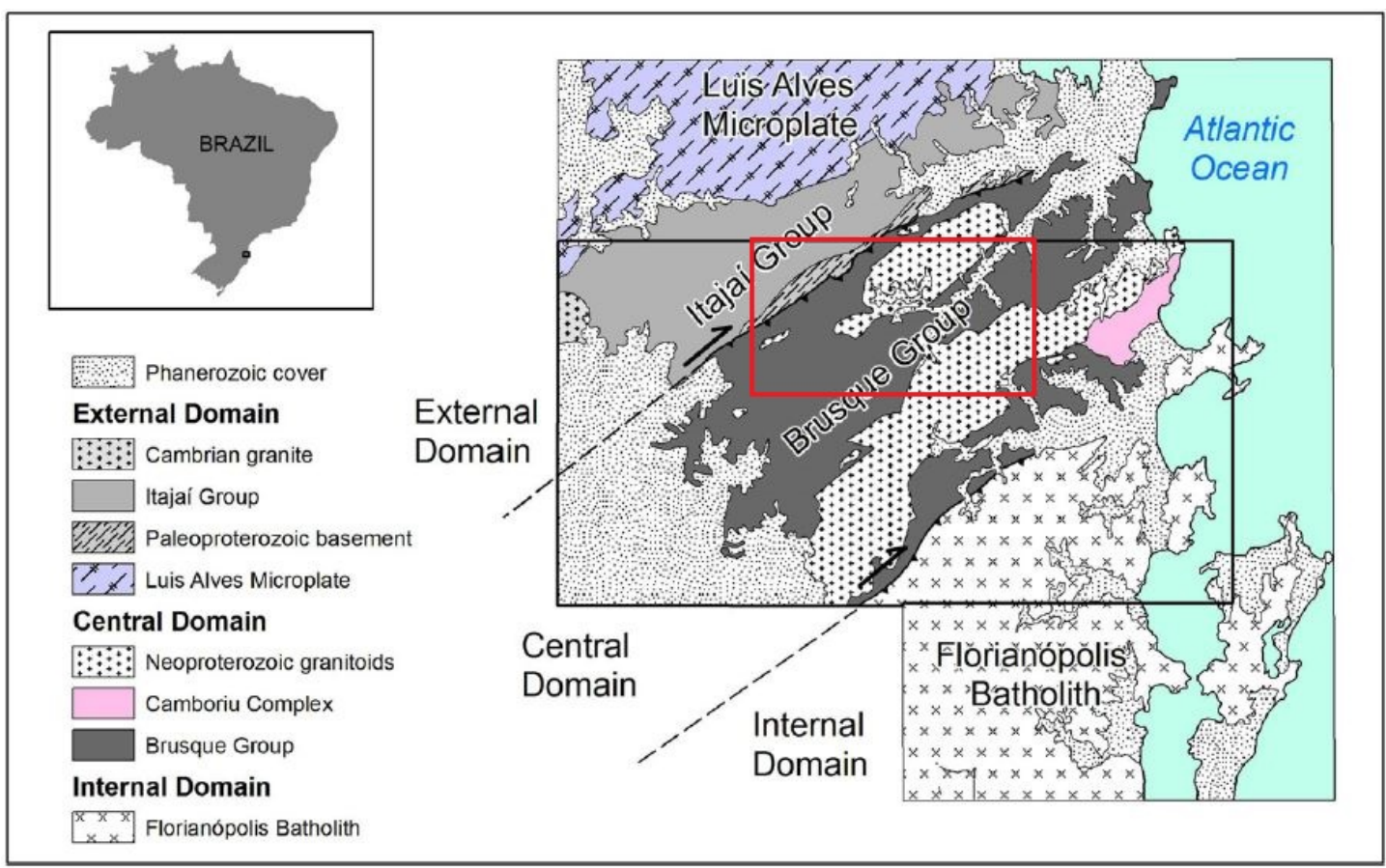

Figure 1 - Geological context of study area (in red). Adapted from Basei et al. (2011a). 


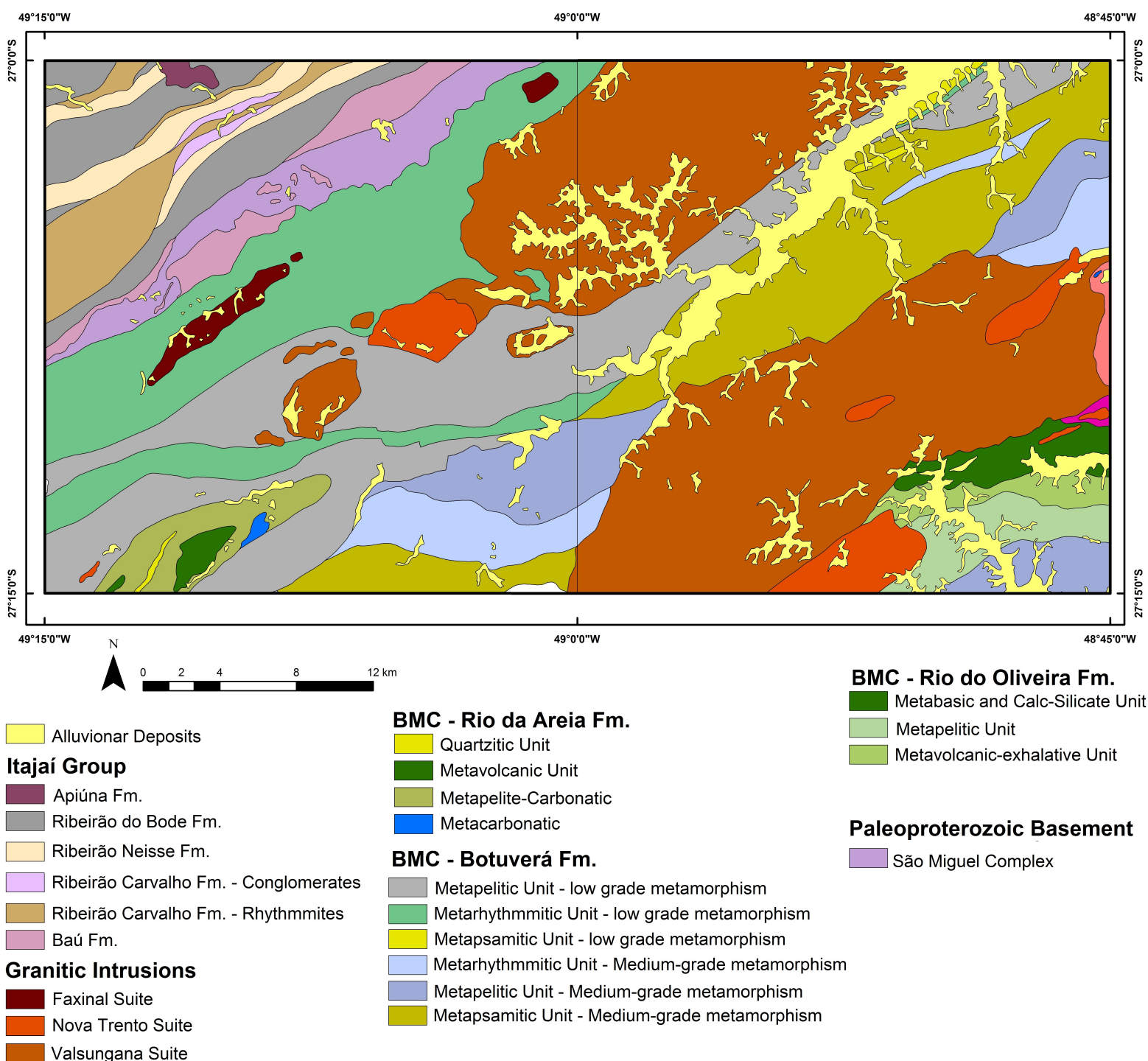

Figure 2 - Detailed geology from study area. Adapted from Basei et al. (2011a); Basei et al. (2014a,b).

An extensive event occurred in the Mesozoic, and is represented by NW-oriented alkaline and basic dykes (Caldasso et al., 1995a,b; Castro et al., 2016).

The study area is placed in the edge of the External and Central domains, affected by the Itajaí-Perimbó Shear Zone (IPSZ), and comprehends the São Miguel and Brusque Metamorphic Complexes (SMC and BMC, respectively), the Valsungana, Guabiruba and Nova Trento igneous suites, the Itajaí Group and many Mesozoic intrusions (Fig. 2).

São Miguel Complex (SMC) occurs northwest of the area, as a monzogranitic and mafic gneiss, locally quartz-feldspatic, with granulitic derivation NE-SW oriented belt (Basei et al., 2010,
$2011 \mathrm{~b}, \mathrm{a})$. This geological unit is bounded by the IPSZ, and is part of the BMC basement, Basei (2000); Basei et al. (2010, 2011b). Geochronological data indicates a Paleoproterozoic age between 2.1 and 2.2 Ga (Borba \& Lopes, 1983 apud Schroeder, 2006).

The Brusque Metamorphic Complex (BMC) consists in a fold belt limited by IPSZ in the north, and is classified in three formations: Rio da Areia, Botuverá and Rio do Oliveira. Geochronological data suggest that it developed strictly in the Neoproterozoic (Basei et al., 2011b).

Rio da Areia Formation comprises four units: (a) Metavolcanic Unit: metamafic to metaultramafic rocks; (b) Quartzitic Unit: orthoquartzites, micaceous and feldspatic 
quartzites and quartz-muscovite schists; (c) Metacarbonatic Unit: calcitic and dolomitic marbles, metamarls and calc-schists; and (d) Metapelite-Carbonatic Unit: metalimestones, metamarls, calc-schists and schists. Botuverá Formation is divided into three units; (a) Metapelitic Unit: characterized by schists; (b) Metarhythmitic Unit: phylites, psamitic-predominance rhythmites and schists; and (c) Metapsamitic Unit: orthoquartzites and micaceous quartzites. Rio do Oliveira Formation is formed by four units; (a) Metapsamitic Unit: orthoquartztites, rhythmites interleaved with schists, quartzites, paraconglomerates and banded iron formations; (b) Metapelitic Unit: micaschists interleaved with amphibolites, quartzites and calc-silicatic rocks; (c) Metavolcano-Exhalative Unit: tourmalinites interleaved with tourmaline-bearing quartzites and carbonatic rocks; and (d) Metabasic and Calc-Silicatic Unit: fine to medium grained amphibolites.

An expressive sin to tardi-tectonic granitogenesis occurred in DFB, and is characterized by the Valsungana, Nova Trento and São João Batista igneous suites (Castro, 1997; Basei, 2000; Basei et al., 2011a; Hueck et al., 2016). Geochemical data points to an intense crustal signature, relating these intrusions to the BMC and its basement (Hueck et al., 2016), and classifying them as peraluminous or metaluminous, from calc-alkaline series, S type granitoids. Geochronology suggests ages between 620 and 580 Ma (Basei, 1985; Silva, 1991; Basei et al., 2011b; Hueck et al., 2016).

The Valsungana Suite consists of two plutons stretched in a NE direction, named South Valsungana and North Valsungana, in addition to other smaller intrusions around it, composed of biotite-monzogranites to syenogranites and coarse-grained to porphyritic granodiorites (Basei, 1985; Silva, 1991; Caldasso et al., 1995a,b; Basei et al., 2011a; Wildner et al., 2014; Hueck et al., 2016). The Nova Trento Suite occurs as stocks intruded in both the BMC and Valsungana Suite, with monzogranitic to syenogranitic composition (Wildner et al., 2014). Some intrusions of this suite tend to the alkaline series. The São João Batista Suite is characterized by stocks placed around the Valsungana granites, exhibiting abrupt, occasionally gradual contacts, suggesting its contemporaneity (Basei, 2000; Basei et al., 2011b). Its composition varies between alkali-feldspar granite, syenogranite and leucocratic-hololeucocratic monzogranite (Hueck et al., 2016).

The Itajaí Group consists of a volcano-sedimentary sequence formed due to a crustal subsidence (Rostirolla et al.,
1992; Schroeder, 2006; Basei et al., 2011b). This basin is in contact SMC and BMC in study area. Geochronological data indicates sedimentation in the Neoproterozoic, beginning in $600 \mathrm{Ma}$. and ending in $560 \mathrm{Ma}$, while magmatism and deformation extended further until $40 \mathrm{Ma}$ (Basei, 1985; Basei et al., 2011b). The Itajaí Group is divided, from base to top, in five formations: Baú Formation, characterized by alluvial fan sandstones and conglomerates; Ribeirão Carvalho Formation, formed by siltic-argillaceous rhythmmitic turbidites; Rio Neisse Formation, consisted of arcosean sandstone and submarine channel and fan siltstones; Ribeirão do Bode Formation, corresponding to distal siltic turbidites; and Apiúna Formation, represented by volcanic felsic rocks (Basei et al., 2011b).

Mesozoic magmatism is expressed by basic and alkaline dykes, mainly oriented to the NW-SE direction. Generally, they are fine to medium grained with equigranular texture (Caldasso et al., 1995a,b; Wildner et al., 2014).

Several shear zones cross the study area, in especial the Itajaí-Perimbó Shear Zone (IPSZ), a set of thrust and transcurrent faults associated in a complex geometry of braided patterns, characterized by ductile, ductile-ruptile and, locally, ruptile structures (Basei, 1985, 2000; Caldasso et al., 1995a; Biondi et al., 1992; Schroeder, 2006), which separates the External and Central domains of the DFB. Other shear zones influence the Au mineralization directly, as can be seen by the veins' attitudes shown in Biondi et al. (2007).

The studied primary gold mineralization is characterized as quartz veins with iron oxides, pyrite, chalcopyrite and galena, occasionally bearing silver and tungsten, generally NE-SW to E-W oriented, and defined as of plutonic magmatic-hydrothermal type, influenced by shear zones activation (Caldasso et al., 1995a,b; Castro, 1997; Castro et al., 1999; Biondi et al., 2007). These deposits were formed by granitic plutons, with the generation of potassic, phyllic and propilitic alteration zones during a first hydrothermal phase, where gold was formed next to the phyllic zone. A second hydrothermal phase developed after a fault reactivation event, which deformed the veins and mobilized the ore Biondi et al. (2007). The main magmatic mineralization exhibit average Au contents of 6 to 9 ppm and 3,5 ppm of Ag.

\section{DATA AND METHODS}

The present work used geophysical data from the Paraná - Santa Catarina Aerogeophysical Project (PRSCP) (CPRM - Serviço Geológico do Brasil, 2011), geologic data from Basei (2014) and digital elevation model from the Shuttle Radar Topography 
Mission (SRTM) extracted from Nacional Insitute for Spacial Research (INPE), all integrated into a Geographic Information System (GIS).

The PRSCP surveyed the east portion of Santa Catarina and acquired magnetic and radiometric data in a sampling interval of approximately 6 and 60 meters, respectively, in flight and control lines of 500 and 10000 meters, oriented to NS and EW directions, respectively. The average fight height was of 100 meters. The applied pre-processing methods were leveling and micro-leveling of the profiles. In magnetometry, the diurnal magnetic variation and International Geomagnetic Reference Field (IGRF) were subtracted from the data. In gamma-ray spectrometry, the dead time, parallax error, Compton effect, flight height, cosmic radiation, radonium and airplane background were corrected.

\section{Gamma-ray Spectrometry}

Gamma-ray spectrometry method measures contents of potassium, uranium and thorium in the surface through the detection of their gamma-ray emissions (Dickson \& Scott, 1997; Minty, 1997). Potassium presents concentration of $1.5 \%$ in the upper crust, commonly occurs in potassic feldspar, mica group minerals and clay-minerals, and is an important guide to define mineralized areas (Ostrovskiy, 1973; Gnojek \& Prichystal, 1985; Portnov, 1987; Shives et al., 2000) Uranium and thorium are less abundant (2.7 ppm and 10.5 ppm in the upper crust, respectively), and frequently evidence post-magmatic and hydrothermal processes, eventually related to mineralization (Ulbrich et al., 2009). The geochemical behavior of these elements allows observing hydrothermal, metamorphic and geomorphological processes (Ulbrich et al., 2009; ABD El Nabi, 2011; Ribeiro et al., 2013). By establishing relations between them, such as F Parameter, Efimov (1978) apud Gnojek \& Prichystal (1985), and the suggestive parameters for hydrothermal alteration $-\mathrm{Kd}$ and Ud, from Saunders et al. (1994), these processes can be highlighted (Ostrovskiy, 1973; Portnov, 1987).

The F Parameter, is defined by the formula $\mathrm{F}=\mathrm{K}^{*}(\mathrm{eU} / \mathrm{eTh})$. Its main objective is to highlight the abundance of potassium and the eU/eTh ratio simultaneously, evidencing hydrothermal alteration zones eventually related to mineralization (Gnojek \& Prichystal, 1985). Kd and Ud, defined by Saunders et al. (1994), are based on thorium, potassium and uranium concentrations on the surface, which are distributed according to the functions established between ideal (Ki and $\mathrm{Ui}$ ) and observed values (Ks and $U s): K d=(K s-K i) / K i$ and $U d=(U s-U i) / U i$. From these values, potassium and uranium anomalies, generally associated with hydrothermal processes (Pires, 1995) are enhanced.

\section{Magnetometry}

The magnetic method measures the Total Magnetic Intensity (TMI), originated from crustal (Telford et al., 1990). Before the use of magnetic anomalies enhancing methods, magnetic data were reduced to the pole, simulating the data acquisition on the Magnetic Pole, and centering the anomalies over their sources. The magnetic anomalies enhancing methods consist in a series of derivations of local magnetic anomalies, in order to evidence certain features.

The Total Horizontal Gradient (THDR) is obtained from horizontal derivatives, and highlights abrupt variations of the signal on a regular grid, underlining the edges of magnetic bodies (Cordell \& Grauch, 1985). The Analytic Signal Amplitude (ASA) consists in a symmetric function between the horizontal and vertical derivatives, enhancing the edges of large bodies or the center of narrow bodies, and the amplitudes are directly related to the sources' depth (Nabighian, 1972; Cordell \& Grauch, 1985; Roest et al., 1992). The Tilt Angle (TDR) is defined by the angle between the vertical derivative and the THDR, and equalizes the anomaly amplitudes, so that the signal responds the same way to all depths. Another Important TDR property is that the signal is on the center of the anomaly (Miller \& Singh, 1994). The use of TDR over THDR (TAHG) reveals features not clearly identified by other methods. One of its advantages is exhibiting the borders of bodies in various depths with better resolution (Ferreira et al., 2013). Signum Transform results from the quotient between an $\mathrm{f}$ function and its absolute value, and, because of that, the values are expected to be (1) over the sources and (-1) outside them. The results are signals represented by "plateaus". Signum Transform outlines well borders of dykes and structures well, as it is practically independent of the sources' depth (Souza \& Ferreira, 2012, 2013, 2015).

\section{Data Processing}

Data processing began with the clipping of geophysical data in ( $\mathrm{x}$, $y, z)$ format into the shape of the study area. After that, gamma-ray spectrometric data were interpolated by the minimum curvature method (Briggs, 1974) and disposed in a 100X100 meters grid, using Oasis Montaj ${ }^{\mathrm{TM}}$. After the grid generation, negative values of $\mathrm{K}$, eU and $\mathrm{eTh}$, generated by many corrections applied to the data, were eliminated by adding a constant in a way that minimum value became equal to 0.01 , as can be seen in Table 1. Based on 
the $\mathrm{K}$, eU and eTh corrected grids, F Parameter, Kd and Ud were calculated. Pre-processed magnetic data was organized in a grid by the bi-directional method, and later reduced to the magnetic pole (RTP) (Baranov, 1957; MacLeod et al., 1993). After RTP, the following magnetic anomalies enhancing methods TDHR, ASA, TDR, TAHG and Signum Transform were applied.

Table 1 - Correction applied in radiometric data.

\begin{tabular}{|c|c|c|c|}
\hline Radionuclide & Minimum & AddedValue & CorrectedValue \\
\hline K & 0.16 & 0.00 & 0.16 \\
\hline eU & -2.91 & 2.92 & 0.01 \\
\hline eTh & 0.15 & 0.00 & 0.15 \\
\hline
\end{tabular}

\section{Data Interpretation}

The interpretation of radiometric and magnetic anomalies was done by defining gamma-ray spectrometric domains and magnetic lineaments, which allowed the analysis of geophysical data with the geological context. Gamma-ray spectrometric domains were defined by the identification of $\mathrm{K}$, eU and eTh distribution patterns, and magnetic lineaments were based on the recognition of the magnetic anomalies alignment patterns, classified according to their directions and correlated to the structural framework.

\section{Favorability Zones}

Favorability zones were defined using the Knowledge-Driven method, which is based on data analysis established from a previously determined model. Within this method, Index Overlay, consisting on the overlaying of binary variables related to gold occurrences, classified and weighted according to its relevance to the model, was employed with the application of Boolean operations (Bonham-Carter \& Gubins, 1997; Nobrega, 2001; Madani, 2011). Variables were selected based on primary gold deposit models, of magmatic-hydrothermal or volcano-exhalative types, both influenced by shear zones reactivation, and classified as favorable or non-favorable. Variables were: (a) Geological Units, in which only the granitic intrusions and the Metavolcano-Exhalative Unit from Rio Oliveira Formation were considered favorable, plus a 500 meters wide and weight 2 influence zone; (b) Magnetic Lineaments, divided into the NE+EW directions, weight 3 , and NW direction, weight 1, plus a 250 meters influence zone; (c) Gamma-ray spectrometry, in which areas where the $\mathrm{F}$ Parameter, and $\mathrm{Kd}$ values were over the mean plus one standard deviation were selected, weight 2 , and a 500 meters influence zone and (d) known mineralization, classified in mineral occurrences (weight 1) and deposits (weight 2), plus a 500 meters influence zone. Therefore, the formula to establish favorability zones is

$$
\begin{aligned}
F Z & =2 * G e o+3 * N E_{\text {MagLin }}+N W_{\text {MagLin }}+ \\
& +2 * F P+2 * \mathrm{Kd}+O c+2 * D e p,
\end{aligned}
$$

where Geo corresponds to geological units; $N E_{\text {MagLin }}$ to magnetic lineaments NE and EW oriented; $N W_{\text {MagLin }}$ to magnetic lineaments NW oriented; $F P$ to $\mathrm{F}$ Parameter areas; $\mathrm{Kd}$ to Anomalous Potassium areas; $O c$ to mineral occurrences and Dep to deposits.

\section{RESULTS AND DISCUSSIONS}

The results of data processing are presented in Figures 3 to 6 , consisting of maps elaborated and used for geophysical interpretation, and the definition of gamma-ray spectrometric domains and magnetic lineaments.

\section{Radiometric Interpretation}

The analysis of the K-eU-eTh ternary, total count and individual elementary maps allowed the identification of distribution patterns of elements. Thus, areas with similar signature were outlined, as can be seen in Figure 7 . The criteria established to define the domains was the distribution of potassium, uranium and thorium, which were classified as low, medium or high concentration. This way, it was recognized 14 gamma-ray spectrometric domains, as it is shown in Table 2. Figure 8 exhibits these domains overlaid to the geological map.

By comparing the gamma-ray spectrometric domains to the geological context, it was possible to notice a limited relation between both, once the unit contacts and gamma-ray domains borders are partially coincident. Hence, it can be observed that these relations are possibly directly linked to specific areas, especially to granitic intrusions. In other sections, only a certain correlation is recognizable, as the unit contacts and domain borders are merely approximated. The cause for these differences may be associated to the fact that the gamma-ray spectrometric method measures only radiation that comes from the first $40 \mathrm{~cm}$ of surface, being subject to the interference of superficial processes, like mass movements, superficial transportation, weathering and pedogenesis. Still, it was possible to establish some relation between geology and gamma-ray spectrometry.

In general, the BMC units exhibit the lowest radioelements concentration, in particular, the Rio da Areia and Rio Oliveira 


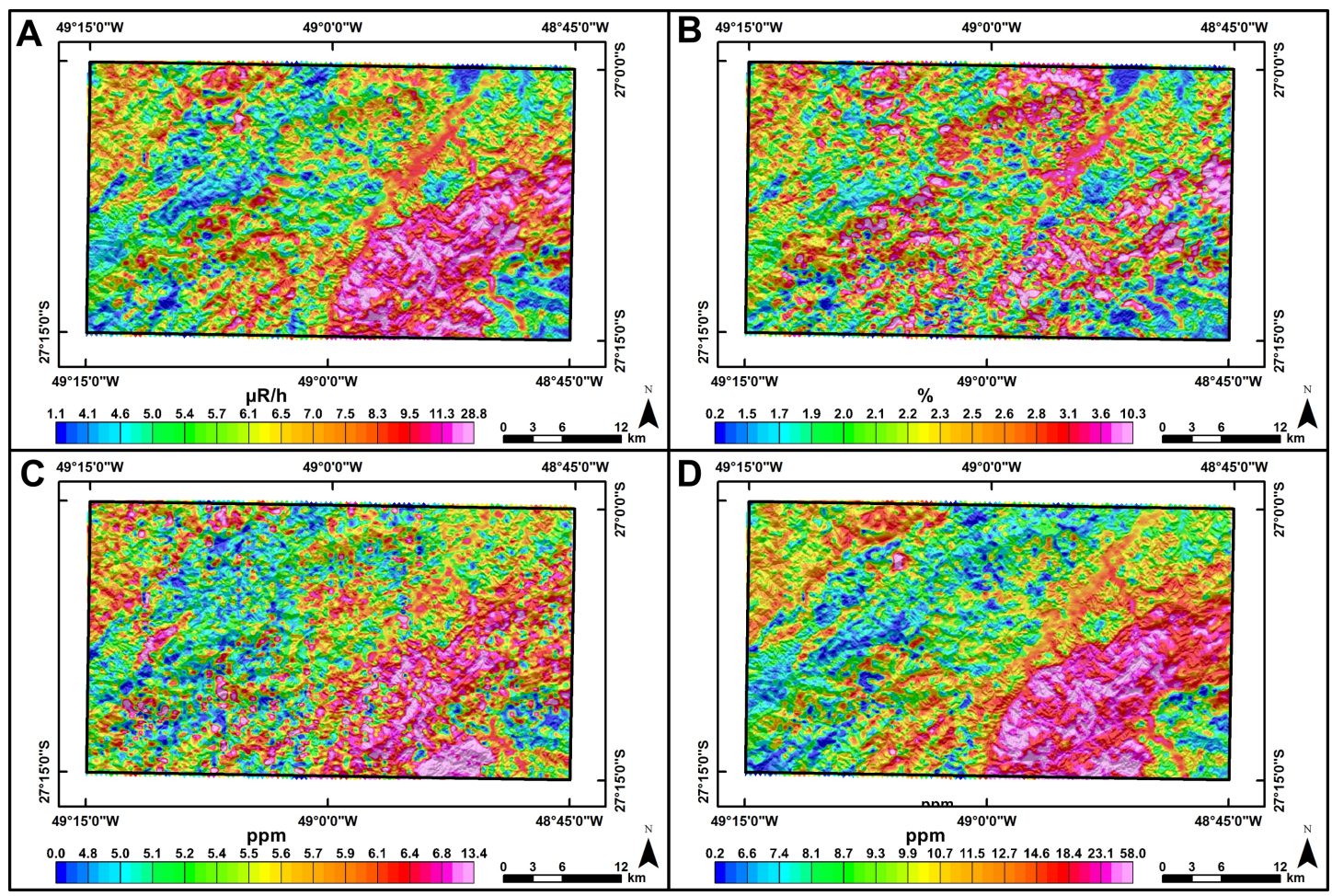

Figure 3 - Gamma-ray spectrometric maps: A) Total Count; B) Potassium; C) Thorium equivalent; D) Uranium equivalent.

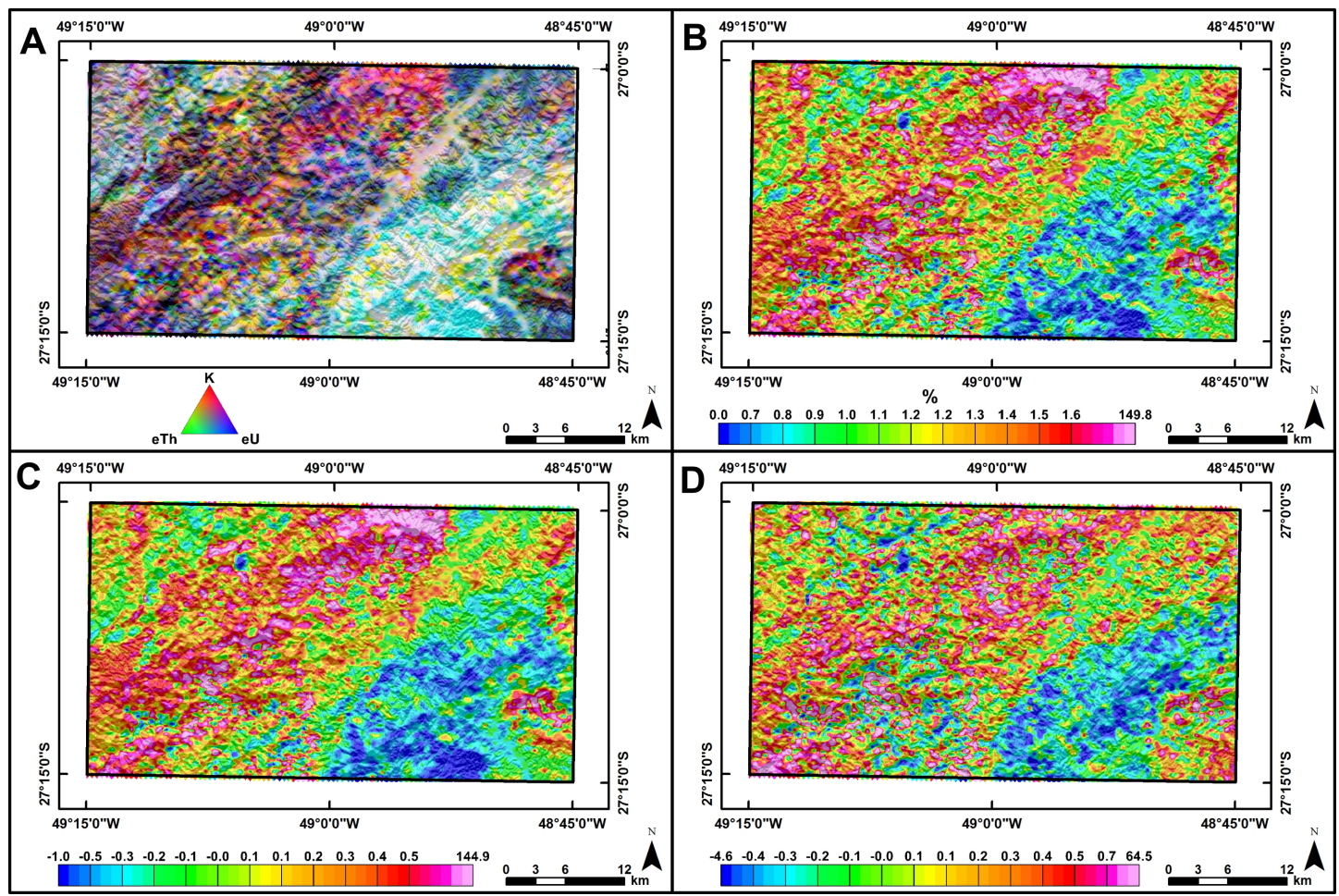

Figure 4 - Gamma-ray spectrometric maps: A) Ternary K-eU-eTh; B) F Parameter; C) Kd; D) Ud. 


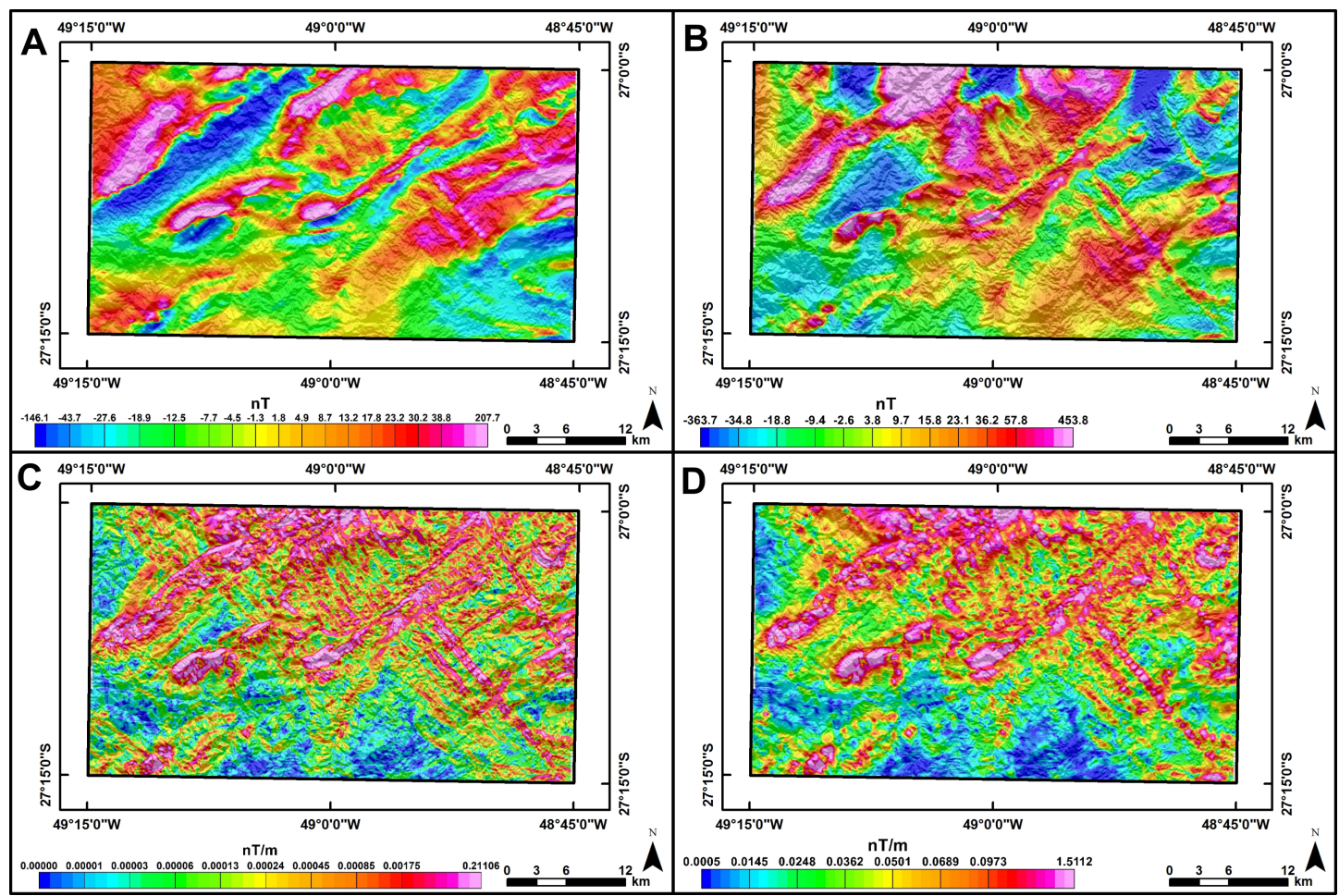

Figure 5 - Magnetic maps: A) TMI; B) TMI reduced to the pole (TMI-RTP); C) THDR; D) ASA.

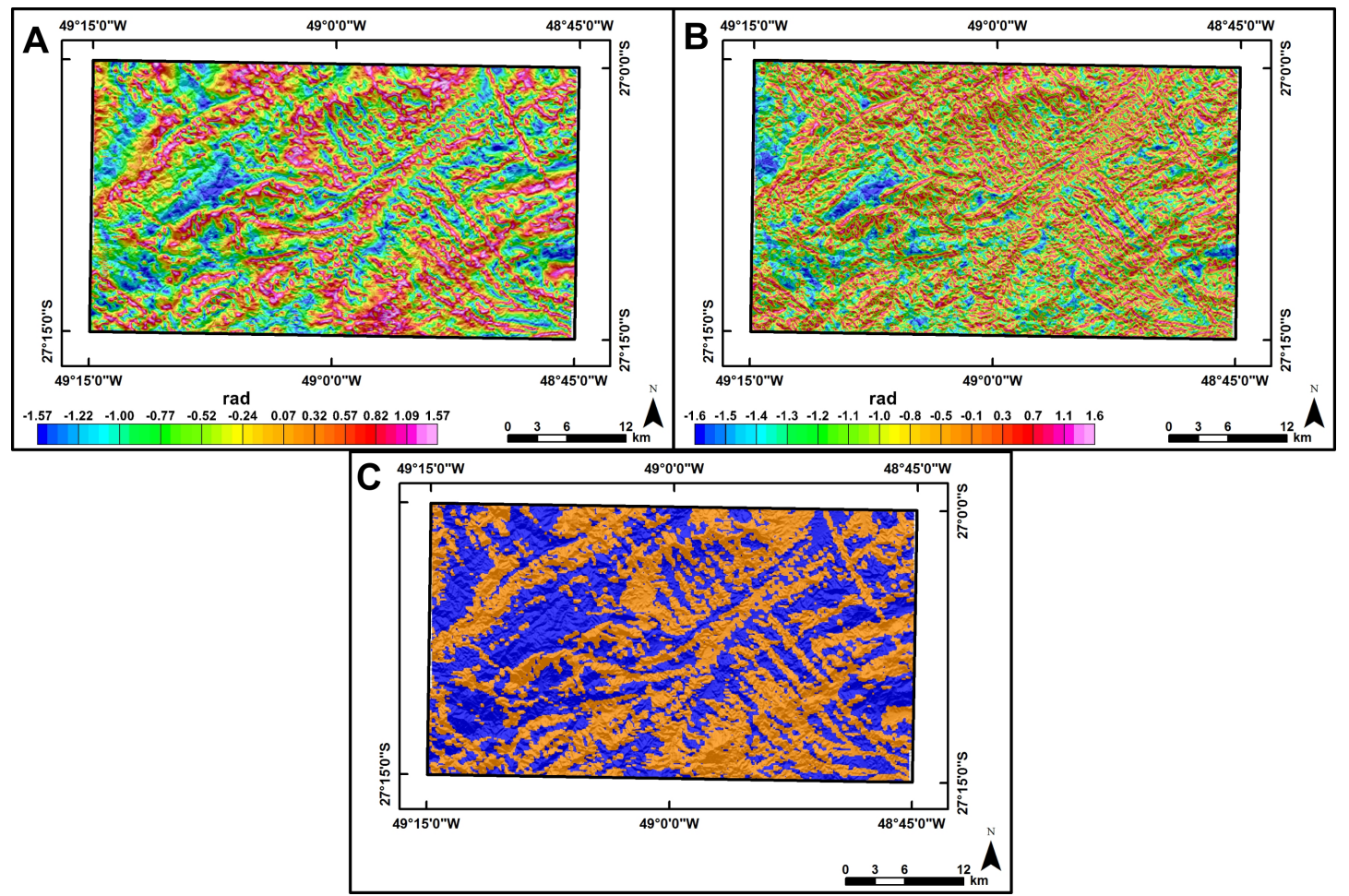

Figure 6 - Magnetic maps: A) TDR; B) TAHG; C) Signum Transform. 


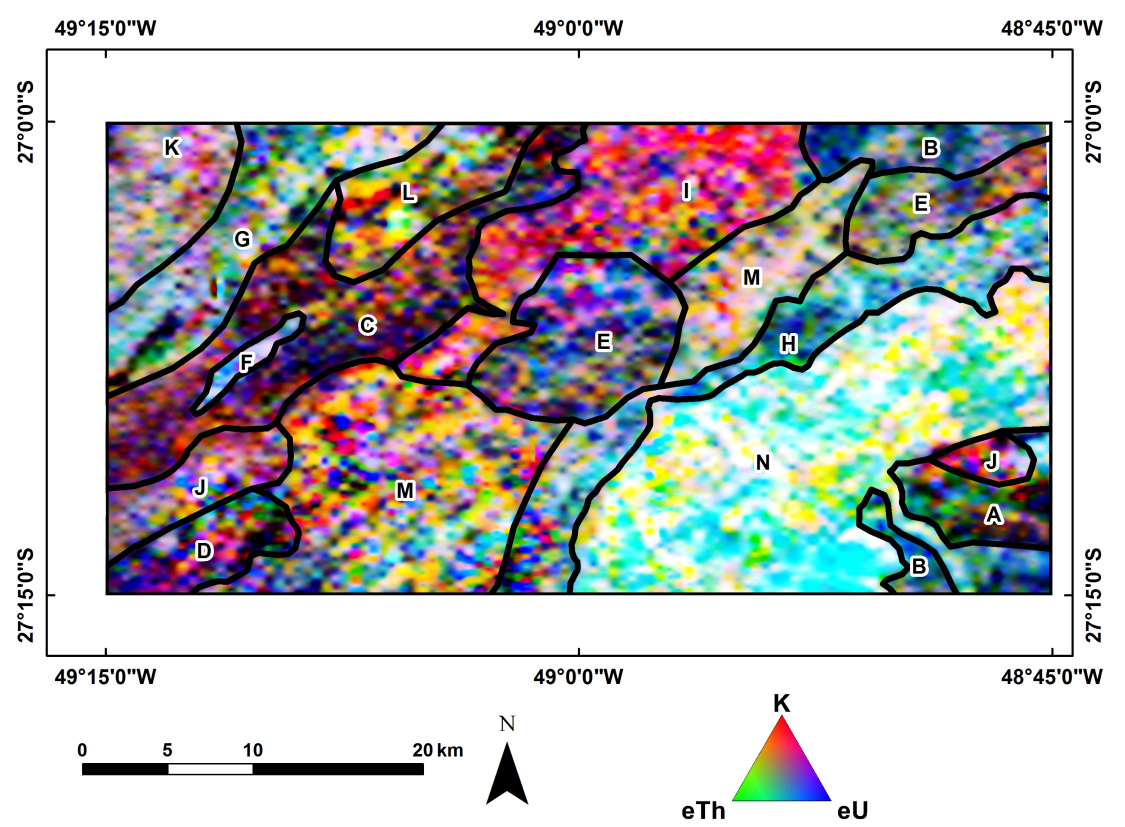

Figure 7 - Gamma-ray spectrometric domains over ternary K-eTh-eU map.

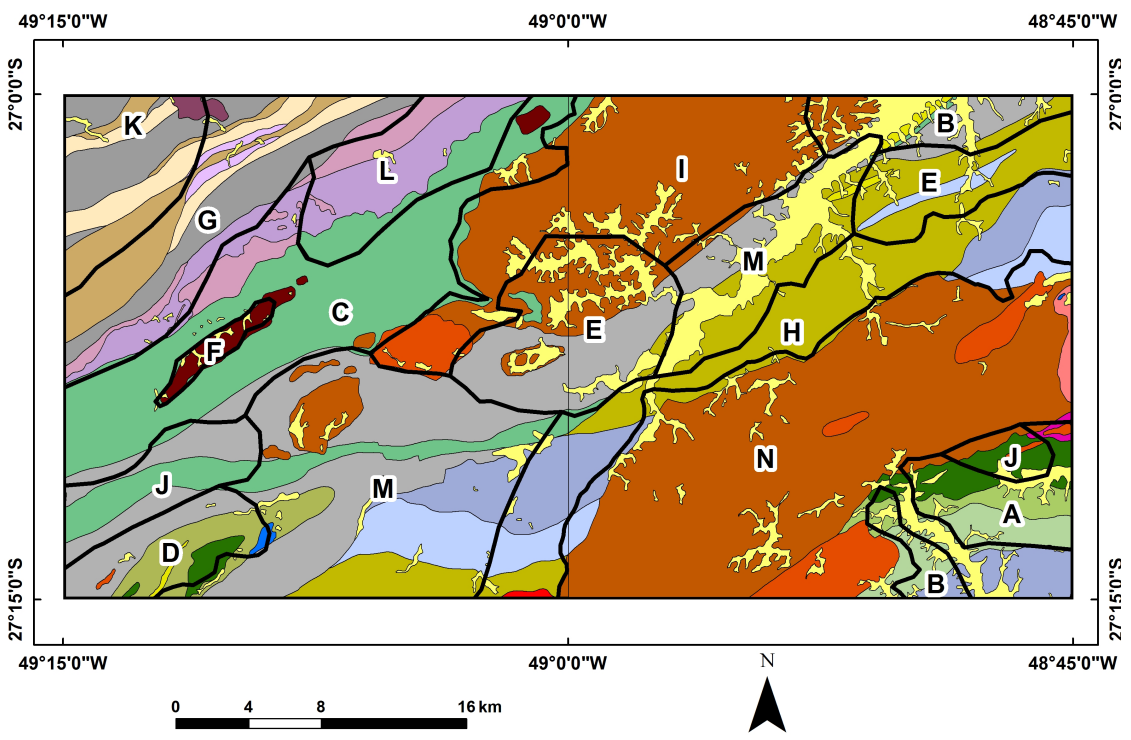

Figure 8 - Gamma-ray spectrometric domains over geological context.

formations, in which units of quartzitic, basic, carbonatic and calc-silicatic composition predominate (A, B, C and D domains). This is possibly due to the composition of these rocks, which is poor in minerals bearing potassium, uranium and thorium.

Close to granitic intrusions, in contact metamorphism zones, uranium and thorium contents tend to be higher, as can be seen in $\mathrm{E}, \mathrm{H}$ and $\mathrm{J}$ domains, probably because of hydrothermal or post-magmatic processes which brought an enrichment in radioactive elements. $\mathrm{F}$ and $\mathrm{N}$ domains are characterized by high $U$ concentrations, and coincide with granitic intrusions named Faxinal and South Valsungana, respectively. These intrusions are composed of biotite-rich monzonites to syenogranites, with uranium possibly being related to biotite and K-feldspar. Finally, I domain, characterized by higher $\mathrm{K}$ contents, coincides with north 


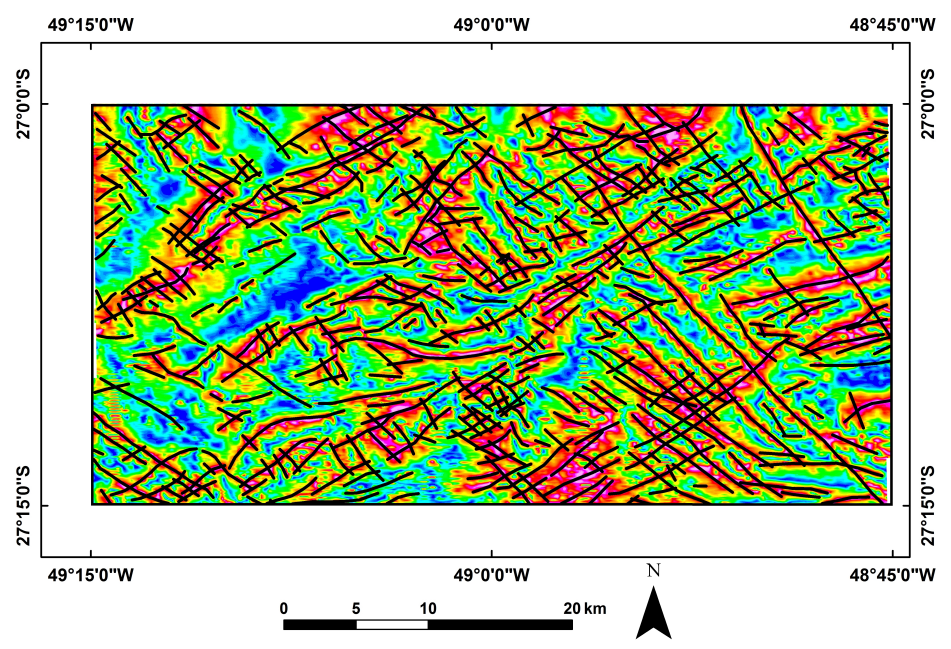

Figure 9 - Magnetic lineaments over TDR map.

Table 2 - Gamma-ray spectrometric domains and associated K. eTh and eU contents.

\begin{tabular}{|c|c|c|c|c|c|c|c|}
\hline DOMAIN & $\mathbf{K}$ & eTh & eU & DOMAIN & $\mathbf{K}$ & eTh & eU \\
\hline A & Low & Medium & Medium & H & Medium & High & High \\
\hline B & Low & Medium & High & $\mathbf{I}$ & High & Low & Medium \\
\hline $\mathbf{C}$ & Medium & Low & Low & J & High & Medium & Medium \\
\hline D & Medium & Low & Medium & $\mathbf{K}$ & High & Medium & High \\
\hline E & Medium & Medium & Medium & $\mathbf{L}$ & High & High & Low \\
\hline F & Medium & Medium & High & $\mathbf{M}$ & High & High & Medium \\
\hline G & Medium & High & Medium & $\mathbf{N}$ & High & High & High \\
\hline
\end{tabular}

to center intrusions of the Valsungana Suite, and is associated to its amount of K-feldspar and probably to potassic hydrothermal alteration zones, except for areas where alluvionar deposits occur, causing interference in the signal.

The Itajaí Group, composed of conglomerates, arkoses and argillites, rocks that are rich in radioactive elements bearing-minerals, such as clay-minerals and K-feldspars, is represented by the $G$ domain, while predominantly arenitic units are associated to lower contents of $\mathrm{K}$ and $\mathrm{U}$, as can be seen in the $\mathrm{K}$ domain. The $\mathrm{L}$ domain is represented by the northern part of the SMC, with high contents of $\mathrm{K}$ and Th, but low $\mathrm{U}$, which is characteristic of gneissic rocks.

\section{Magnetic Lineaments}

Based on the TDR, TAHG and Signum Transform maps, which have their maximum signals centered over the axis and borders of sources, respectively, magnetic lineaments were outlined and interpreted as the response of structures such as faults and shear zones. The magnetic lineaments reveal three main structural trends: NE, E-W and NW, as can be seen in Figure 9.

NE lineaments vary from N30E to N50E, and can be related to the third and fourth deformational events, when thrust faults and shear zones followed by transcurrent structures were formed. As seen in the Figure 10, it is possible to observe three main sets of lineament, which are disposed in the northwestern, central and southeastern areas. The northwestern portion is related to IPSZ and to SMC rocks, once it exhibits a sinuous and braided lineament pattern, similar to the IPSZ geometry. The central lineament set crosses all the study area form SW to NE, and is associated to a series of high to low angle shear zones. Many gold mineralizations are aligned to this group, as shown in Figure 11, denoting a structural control of these occurrences, and turning this set into an important exploratory guide. The southeastern 
group of lineaments is related to structures hosted in the South Valsungana intrusion, which can be observed in digital elevation model.

E-W lineaments are possibly related to the central NE group. These lineaments are less pervasive than others, however, as the central NE lineaments do, they show very intrinsic relation to gold mineralization.

NW lineaments generally exhibit a pattern of long and continuous traces, and are more homogeneously distributed in the study area; however it is possible to notice a higher concentration of those in a central belt, crossing from southeast to northwest. NW lineaments are distributed from N30W to N50W, and many of those coincides with positive structures in terrain, which were interpreted as basic dykes.

\section{Favorability Zones}

The main data integration in this work, however, was developed through the definition of favorability zones, which combined different geophysical and geological data through a mathematical expression, in order to observe their relevance in finding mineralization.

From the application of the favorability formula, the values obtained varied from 0 to 10, and were organized in five classes: very low (0 to 1), low (1 to 3), medium (3 to 5), high (5 to 7 ) and very high ( 7 to 10), as can be seen in Figure 11. Therefore, it was observed that medium to very high favorability zones host known gold occurrences, exhibiting the conformity between both. In fact, the distribution of these medium to very high zones coincides with propitious geological environments for gold mineralization, like the borders of granitic intrusions where shear zone reactivation has happened. Despite the coincidence over favorable areas, some of these zones also occur in areas where geological aspects are not coherent for host mineralization, like areas where NE and NW lineaments cross each other. Due to this disparity, 20 areas with compatible geological context were targeted amongst those with higher chance to host gold mineralization (Fig. 11).

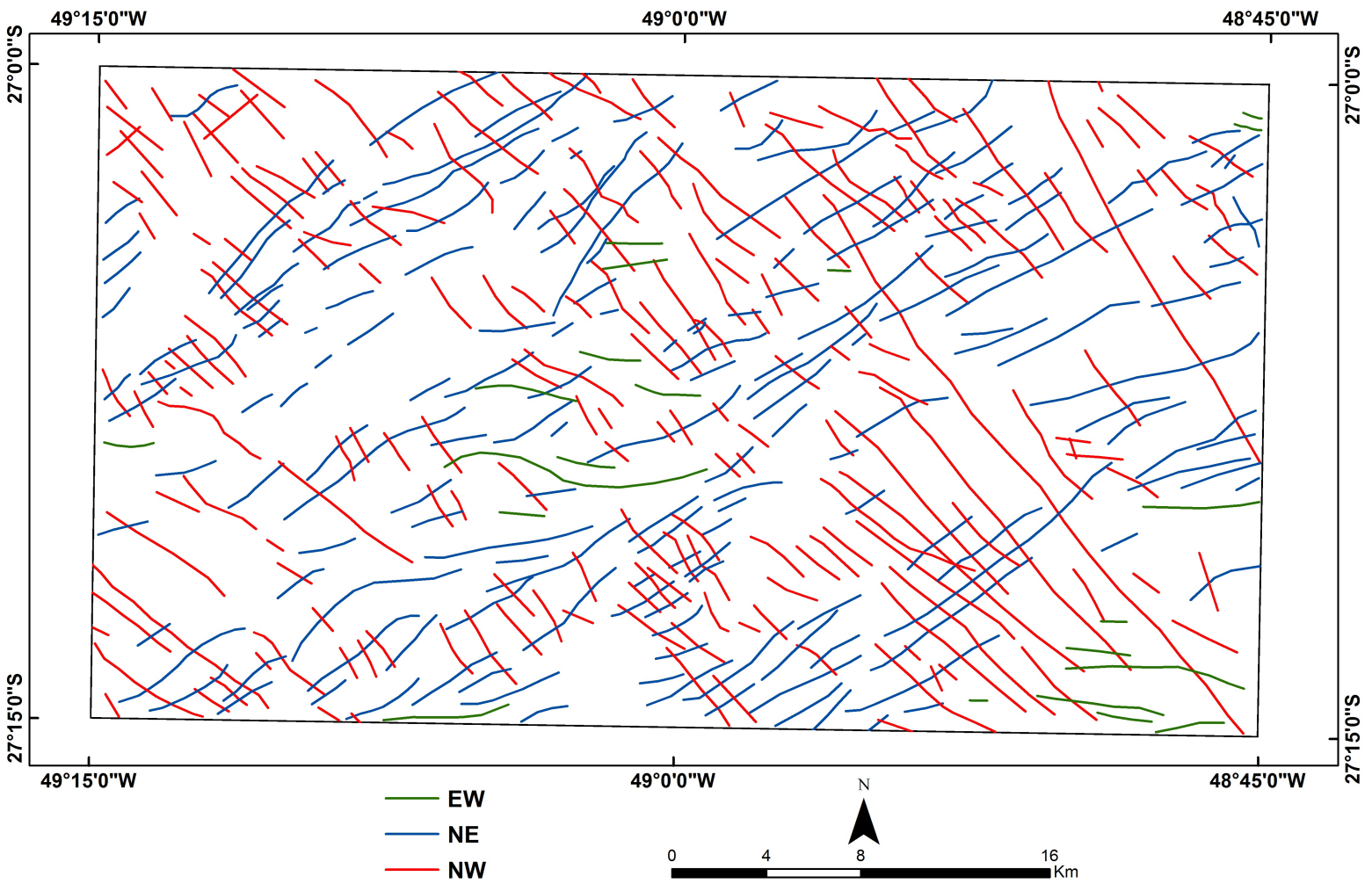

Figure 10 - Magnetic lineaments map, classified according to its directions. 


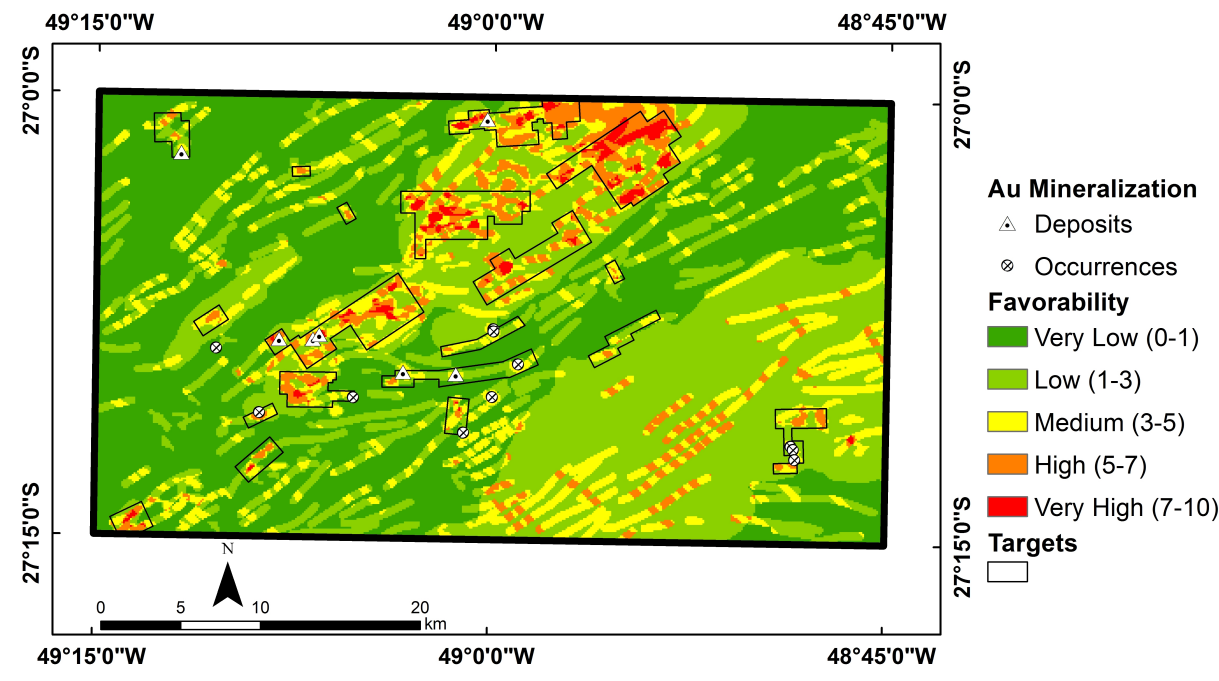

Figure 11 - Favorability zones map.

\section{CONCLUSION}

The integration of geophysical and geological data has led to recognition of favorable for primary gold mineralization. Gamma-ray spectrometry presents considerable correlation to geological units, as can be seen by its domains and correspondent lithotypes. The delimitation of the domains revealed similarity with granitic intrusions and metamorphic zones, and a correlation with the São Miguel Complex, the Brusque Metamorphic Complex and the Itajaí Group. In the BMC, it was possible to distinguish quartz-rich, basic or carbonatic/calc-silicatic units from micaceous, phyllitic, feldspatic or argillaceous to siltic units. Suggestive parameters for hydrothermal alteration, such as $\mathrm{Kd}$, Ud and F Parameter had an important correlation with mineralization occurrences, and, as it is mentioned below, were imprescindible to define the favorability zones.

Magnetic data revealed an important connection between low to high angle shear zones, which cross the study area and with Mesozoic-age basic dykes with magnetic lineaments, making it possible to identify three main directions: NE, E-W and NW. It was also found that NE lineaments located at the center of the area, just as E-W lineaments, have an important relation to gold mineralization, as suggest previous studies. NW lineaments correspond to diabase dykes and Mesozoic-related structures, like faults and joints.

The geophysical-geological integration revealed that the central portion of the study area holds the highest probability to host gold mineralizations, many of which are not known occurrences, indicating great potential for gold exploration. It was also noted that gold occurrences are more related to magnetometry than to gamma-ray spectrometry, suggesting that NE structures are more important for mineralization than potassic and phyllic hydrothermalism associated to granites are.

\section{ACKNOWLEDGMENTS}

The authors grateful to Companhia de Pesquisa de Recursos Minerais - Geological Survey of Brazil (CPRM) for allowing us to use and publish airborne geophysical data in the study area. In this research F.J.F. Ferreira was supported by National Council for Scientific and Technological Development (CNPq) (contract 3069/2015-6).

\section{REFERENCES}

ABD El Nabi SH. 2011. Role of $\gamma$-ray spectrometry in detecting potassic alteration associated with Um Ba'anib granitic gneiss and metasediments, G. Meatiq area, Central Eastern Desert, Egypt. Arabian Journal of Geosciences, 6(4): 1249-1261. doi: 10.1007/s12517-0110378-4.

BARANOV V. 1957. A new method for interpretation of aeromagnetic maps: pseudo-gravimetric anomalies. Geophysics, 22(2): 359-382.

BASEI MAS. 1985. 0 Cinturão Dom Feliciano em Santa Catarina. Ph.D. thesis. Universidade de São Paulo, Brazil. 201 pp.

BASEI MAS. 2000. Geologia e modelagem geotectônica dos terrenos Pré-Cambrianos das regiões sul-oriental brasileira e uruguaia: 
possíveis correlações com províncias similares do sudoeste africano. Professorship Thesis - Instituto de Geociências, Universidade de São Paulo, Brazil. 124 pp.

BASEI MAS, CAMPOS NETO M, CASTRO NA, SANTOS PR \& SIGA JR 0. 2014a. Folha Brusque: SG.22-Z-D-I. Serviço Geológico do Brasil CPRM. Geological Map. Scale 1:100.000.

BASEI MAS, CAMPOS NETO MC, CASTRO NA, NUTMAN AP, WEMMER K, YAMAMOTO MT, HUECK M, OSAKO L, SIGA 0 \& PASSARELLI CR. 2011a. Tectonic evolution of the Brusque Group, Dom Feliciano belt, Santa Catarina, Southern Brazil. Journal of South American Earth Sciences, 32(4): 324-350.

BASEI MAS, CAMPOS NETO MC, CASTRO NA, SANTOS PR \& SIGA JR 0. 2014b. Folha Vidal Ramos: SG.22-Z-D-II. Serviço Geológico do Brasil - CPRM. Geological Map. Scale 1:100.000.

BASEI MAS, DRUKAS CO, NUTMAN AP, WEMMER K, DUNYI L, SANTOS PRD, PASSARELLI CR, CAMPOS NETO MC, SIGA 0 \& OSAKO L. 2011b. The Itajaí foreland basin: a tectono-sedimentary record of the Ediacaran period, Southern Brazil. International Journal of Earth Sciences, 100(2-3): 543-569.

BASEI MAS, NEVES BBB, SIGA JUNIOR 0, BABINSKI M, PIMENTEL MM, TASSINARI CCG, HOLLANDA MHB, NUTMAN A \& CORDANI UG. 2010. Contribution of SHRIMP U-Pb zircon geochronology to unravelling the evolution of Brazilian Neoproterozoic fold belts. Precambrian Research, 183(1): 112-144.

BIONDI JC, FRANKE ND, DE CARVALHO PR \& VILLANOVA SN. 2007. Geologia do depósito de Au Cavalo Branco (Botuverá-SC). Revista Brasileira de Geociências, 37(3): 445-463.

BIONDI JC, SCHICKET G \& BUGALHO A. 1992. Processos mineralizadores em bacias tardi-orogênicas 1. Influência das estruturas rígidas na geração dos depósitos da minepar e do Ribeirão da Prata, grupo Itajaí - (SC). Revista Brasileira de Geociências, 22(3): 275-288.

BONHAM-CARTER GF \& GUBINS AG. 1997. GIS methods for integrating exploration data sets. In: Proceedings of Exploration. Volume 97. p. 59-64.

BRIGGS IC. 1974. Machine contouring using minimum curvature. Geophysics, 39(1): 39-48.

CALDASSO ALS, KREBS ASJ, SILVA MAS, CAMOZZATO E \& RAMGRAB GE. 1995a. Folha Botuverá.SG.22-Z-B-IV-2. Serviço Geológico do Brasil - CPRM. Geological Map. Scale 1:50.000.

CALDASSO ALS, KREBS ASJ, SILVA MAS, CAMOZZATO E \& RAMGRAB GE. 1995b. Folha Brusque: SG.22-Z-D-I-1.SG.22-Z-B-IV-2. Serviço Geológico do Brasil - CPRM. Geological Map. Scale 1:50.000.

CASTRO NA. 1997. Contribuição ao conhecimento geológico-metalogenético associado aos granitoides intrusivos no grupo Brusque (SC) com base em informações geológicas, aerogamaespectrométricas e LANDSAT/TM-5. Master's thesis. Universidade Estadual de Campinas, Campinas, Brazil. 221 pp.

CASTRO NA, BASEI MAS \& CRÓSTA AP. 1999. The W (Sn-Mo)-Specialized Catinga Suite and other Granitoids of the Brusque Group, Neoproterozoic of the State of Santa Catarina, Southern Brazil. Brazilian Journal of Geology, 29(1): 17-26.

CASTRO NA, CRÓSTA AP, FERREIRA FJF, BASEI MAS \& PASCHOLATI ME. 2016. Quadro geológico regional da porção central do embasamento pré-ordoviciano de Santa Catarina com base em imagens LANDSAT-5/TM e aerogeofísicas. Revista Brasileira de Geociências, 33(suppl. 2): 161-172.

CORDELL L \& GRAUCH VJS. 1985. Mapping basement magnetization zones from aeromagnetic data in the San Juan Basin, New Mexico. In: HINZE WJ (Ed.). The utility of regional gravity and magnetic anomalies maps, p. 181-197. Society of Exploration Geophysicists.

CPRM - Serviço Geológico do Brasil. 2011. Projeto Aerogeofísico Paraná-Santa Catarina. Relatório final do levantamento e processamento dos dados magnetométricos e gamaespectrométricos. Brazil.

DICKSON BL \& SCOTT KM. 1997. Interpretation of aerial gamma-ray surveys-adding the geochemical factors. AGSO Journal of Australian Geology and Geophysics, 17: 187-200.

FERREIRA FJF, DE SOUZA J, DE B E S BONGIOLO A \& DE CASTRO LG. 2013. Enhancement of the total horizontal gradient of magnetic anomalies using the tilt angle. Geophysics, 78(3): J33-J41.

FORNAZZARI NETO L \& FERREIRA FJF. 2003. Gamaespectrometria integrada a dados exploratórios multifonte em ambiente SIG aplicada à prospecção de ouro na Folha Botuverá, SC. Revista Brasileira de Geociências, 33(suppl. 2): 197-208.

GNOJEK I \& PRICHYSTAL A. 1985. A new zinc mineralization detected by airborne gamma-ray spectrometry in northern Moravia (Czechoslovakia). Geoexploration, 23(4): 491-502.

HUECK M, BASEI MAS \& DE CASTRO NA. 2016. Origin and evolution of the granitic intrusions in the Brusque Group of the Dom Feliciano Belt, south Brazil: Petrostructural analysis and whole-rock/isotope geochemistry. Journal of South American Earth Sciences, 69: 131-151.

IRVINE RJ \& SMITH MJ. 1990. Geophysical exploration for epithermal gold deposits. Journal of Geochemical Exploration, 36(1-3): 375-412.

MACLEOD IN, JONES K \& DAI TF. 1993. 3-D analytic signal in the interpretation of total magnetic field data at low magnetic latitudes. Exploration Geophysics, 24(3 and 4): 679-688.

MADANI AA. 2011. Knowledge-driven GIS modeling technique for gold exploration, Bulghah gold mine area, Saudi Arabia. The Egyptian Journal of Remote Sensing and Space Science, 14(2): 91-97. 
MILLER HG \& SINGH V. 1994. Potential field tilt-a new concept for location of potential field sources. Journal of Applied Geophysics, 32(2-3): 213-217.

MINTY BRS. 1997. Fundamentals of airborne gamma-ray spectrometry. AGSO Journal of Australian Geology and Geophysics, 17: 39-50.

NABIGHIAN MN. 1972. The analytic signal of two-dimensional magnetic bodies with polygonal cross-section: its properties and use for automated anomaly interpretation. Geophysics, 37(3): 507-517.

NOBREGA RPD. 2001. Análise espacial 'knowledge-driven' e 'data-driven': 0 uso das logicas booleana, fuzzy e redes neurais para geração de mapas de favorabilidade mineral na região centro-leste da Bahia. Master's thesis. Universidade Estadual de Campinas, Campinas, Brazil. 72 pp.

OSTROVSKIY EY. 1973. Antagonism of radioactive elements in wallrock alterations fields and its use in aerogamma spectrometric prospecting. International Geology Review, 17(4): 461-468.

PIRES ACB. 1995. Identificação geofísica de áreas de alteração hidrotermal, Crixás-Guarinos, Goiás. Revista Brasileira de Geociências, 25(1): 61-68.

PORTNOV AM. 1987. Specialization of rocks toward potassium and thorium in relation to mineralization. International Geology Review, 29(3): 326-344.

RIBEIRO VB, MANTOVANI MSM \& LOURO VHA. 2013. Aerogamaespectrometria e suas aplicações no mapeamento geológico. Terræ Didatica, 10(1): 29-51.

ROEST WR, VERHOEF J \& PILKINGTON M. 1992. Magnetic interpretation using the 3-D analytic signal. Geophysics, 57(1): 116-125.

ROSTIROLLA SP, ALKMIM FFD \& SOARES PC. 1992. 0 grupo Itajaí, estado de Santa Catarina, Brasil: exemplo de sedimentação em uma bacia flexural de antepaís. Boletim de Geociências da Petrobras, 6(3): 109-122.

SAUNDERS DF, BRANCH JF \& THOMPSON CK. 1994. Tests of Australian aerial radiometric data for use in petroleum reconnaissance. Geophysics, 59(3): 411-419.
SCHROEDER GS. 2006. Análise tectônica da Bacia de Itajaí. Master's thesis. Instituto de Geociências, Universidade Federal do Rio Grande do Sul, Porto Alegre, Brazil. 109 pp

SHIVES RBK, CHARBONNEAU B \& FORD KL. 2000. The detection of potassic alteration by gamma-ray spectrometry-Recognition of alteration related to mineralization detecting ore using GRS and $\mathrm{K}$ alteration. Geophysics, 65(6): 2001-2011.

SILVA LC. 1991. 0 Cinturão Metavulcanossedimentar Brusque e a evolução policíclica das faixas dobradas Proterozóicas no sul do Brasil: uma revisão. Revista Brasileira de Geociências, 21(1): 60-73.

SOUZA J \& FERREIRA FJF. 2012. On the use of derivatives for interpreting magnetic anomalies due to dyke-like bodies: Qualitative and quantitative analysis. In: SEG Technical Program Expanded Abstracts. Society of Exploration Geophysicists. International Geophysical Conference and Oil \& Gas Exhibition, Istanbul.

SOUZA J \& FERREIRA FJF. 2013. On the use of Derivatives for Interpreting Magnetic Anomalies due to Dyke-Like Bodies II: Application to Synthetic and Field Data. In: SEG Technical Program Expanded Abstracts. Society of Exploration Geophysicists. International Geophysical Conference and Oil \& Gas Exhibition, Houston.

SOUZA JD \& FERREIRA FJF. 2015. The application of Signum Transform to the interpretation of magnetic anomalies due to prismatic bodies. In: SEG Technical Program Expanded Abstracts. Society of Exploration Geophysicists. 24th International Gephysical Conference and Exhibition. Perth.

TELFORD WM, GELDART LP, SHERIFF RE \& KEYS DA. 1990. Applied Geophysics. Volume 1. Cambridge University Press. 770 pp.

ULBRICH HHGJ, ULBRICH MNC, FERREIRA FJF, ALVES LS, GUIMARÃES GB \& FRUCHTING A. 2009. Levantamentos gamaespectrométricos em granitos diferenciados. I: revisão da metodologia e do comportamento geoquímico dos elementos $\mathrm{K}$, Th e $\mathrm{U}$. Revista do Instituto de Geociências - USP, 9(1): 33-53.

WILDNER W, CAMOZZATO E, TONIOLO JA, BINOTTO RB, IGLESIAS CMF \& LAUX JH. 2014. Geological Map of the State of Santa Catarina. Porto Alegre, Brazil. CPRM. Scale 1:500.000. 